\title{
Skinn- og pelsberedning i reinsdyrkulturer
}

\section{- en sammenlignende studie av samiske og evenkiske metoder. Kon- serveringsvitenskapelige perspektiver på nedbrytning og bevaring av museumssamlinger av skinn og pels}

Publiserte beretninger av skinn- og pelsberedningsmetoder hos reinsdyrkulturer i nordeurasiske områder er få og generaliserende. Gudmund Hatt er et unntak og har gitt et viktig bidrag til forståelsen av de prosesser som gjennomføres i beredningen av ulike skinn- og pelsmaterialer i eurasiske kulturer. Tross dette er beskrivelsene begrenset og redegjør ikke for den tidsmessige og geografiske dynamikk som kan iakttas innenfor teknologi og materialbruk spesielt i perioden fra 1914 til i dag. Beretninger om samiske beredningsmetoder begrenses i stor grad til beskrivelser av barkgarvet skinn og noe spredt informasjon finnes om fettgarving. Beretninger av skinn- og pelsberedningsmetoder blant urfolk i Sibir er like generaliserende og mangelfulle. Under feltarbeidet i 3 ulike områder i Sibir (1998-2004) kom det under intervjuene med Evenkiske kvinner fram en variasjon og fleksibilitet $\mathrm{i}$ skinnberedningsmetode og materiale som tilsier at metodene ikke er avhengig av et bestemt materiale og en bestemt prosess - men av valg innen mer eller mindre tradisjonsbestemte grupper av materialer og metoder. Metodene er dynamiske, de varierer med tid og sted og er blant annet avhengig av tilgjengelige naturressurser, tillært metode og lokal tradisjon.

\section{KOMPARATIVE STUDIER}

Prosjektet tar utgangspunkt i nordsamisk område $\mathrm{i}$ Norge med komparative studier i russisk område, blant Evenkene i midt og nordøst Sibir. Hvilke skinn- og pelsmaterialer som anvendes, hvorfor nettopp disse materialer anvendes, hvilke garvestoffer og tilsetningsstoffer som anvendes og hvordan de ulike trinn i prosessen foregår (slakting, rensing, avhåring, tørking, garving, mykgjøring, mekanisk bearbeidelse) for materialer med ulike egenskaper og anvendelsesområder samt hvilke variasjoner som kan dokumenteres, kartlegges gjennom feltstudier. 
Vi står i dag overfor flere utfordringer med hensyn til hvordan vi musealt og konserveringsmessig skal og kan ta vare på gjenstander av skinn og pels og hvordan vi skal bevare de informasjoner og den tradisjonelle kunnskap som er knyttet til dem. Bruken av pels og skinn som materialer til hverdagstøy faller gradvis bort ettersom tradisjonsbærere blir færre og det etterlates lite eller ingen skriftlig dokumentasjon. Kunnskapen ligger nå i stor grad hos den eldre generasjon og det er ikke lenger en selvfølge at denne overføres til den yngre generasjon. Det skjer en sentralisering av kunnskap til et færre antall personer. Hvilke konsekvenser har dette for utviklingen av beredningsteknologi og ikke minst for diversiteten i beredningsteknologi?

En av de endringer som har skjedd i de siste generasjoner er at drakten og/eller draktelementene benyttes i større grad som identitetsskapende og nasjonsfremmende elementer enn som hverdagstøy. Nasjonaldager, festivaler, høytider og rituelle sammenkomster er blant andre typiske dager/perioder hvor draktene brukes. Likevel er det innenfor det arktiske og subarktiske område naturgitte forhold, hvor man kan tenke seg at teknologien likevel ikke vil forsvinne helt. Når temperaturen synker er det fortsatt reinsdyrets pels som kan gi den beste beskyttelse mot kulden.

\section{BEVARING AV GJENSTANDER}

Et vesentlig element i fremtidig bevaring av skinn- og pelsgjenstander og samlinger er kunnskapen om hvilke materialer og metoder som er anvendt på de aktuelle gjenstander på det aktuelle tidspunkt. Likeledes er det viktig

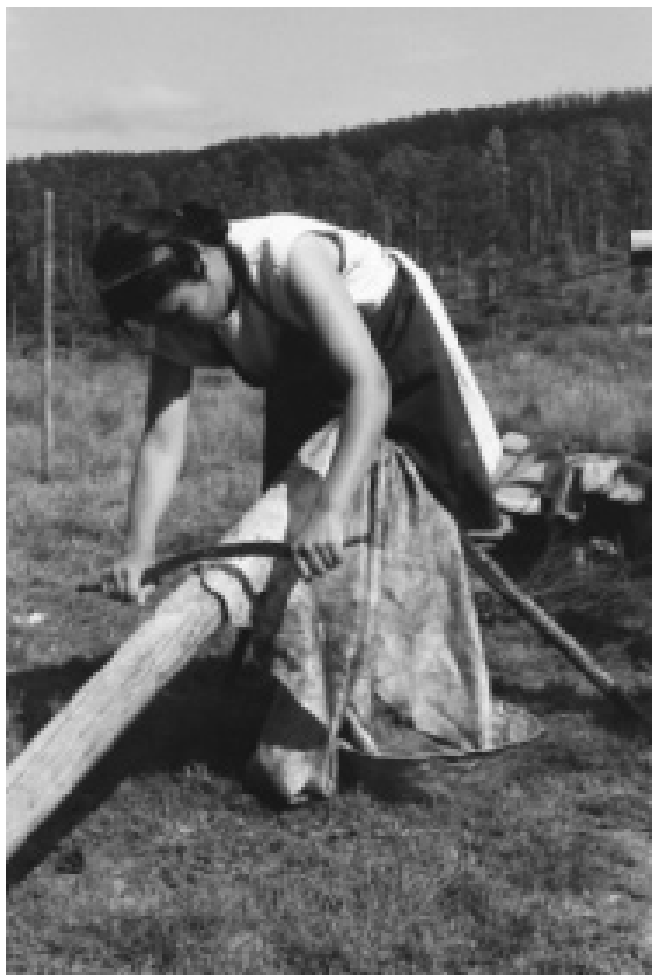

Kuzmina Julia Anatolievna fra Nichatka, Transbaikal, Russland, skraper reinsdyrskinn med en tohändsskrape. Fotograf: T. Klokkernes, 2000. (C) KHM, UiO.

å kartlegge hvordan de benyttede beredningsmetoder påvirker gjenstandsmaterialet i bevaringssammenheng. Prosjektet klassifiserer observerbare karakteristika i forhold til metode/prosess gjennom visuelle/mikroskopiske metoder og gjennom ulike analyser. De mest anvendte analysemetoder for kartlegging av identifiserbare tilsetningsstoffer, fargestoffer og garvestoffer de senere år er separeringsmetoder/kromatografiske metoder, spektrometriske metoder og termiske metoder som krympingstemperatur. Resultatene vurderes i forhold til beredningsmetodene og deres inn- 
virkning på tilstand og nedbrytningsforløpet for gjenstandsmaterialet. Innenfor studiet av arktisk og subarktisk gjenstandsmateriale fra urfolk er det foreløpig bare gjort begrensede analyser av gjenstandsgrupper fra Nunavut og Grønland mens det samiske og sibirske materialet ikke tidligere har vært gjenstand for denne type undersøkelser.

I tidlig bevaringshistorie har det etnografiske gjenstandsmaterialet som finnes på museer til dels blitt behandlet ulikt fra annet musealt gjenstandsmateriale. Mens man innenfor etnologisk gjenstandsmateriale på enkelte konserveringsvitenskapelige områder har tatt utgangspunkt i de opprinnelige vedlikeholdsmetoder for bevaring av gjenstandene, har eksisterende etnografisk gjenstandsmateriale blitt satt i samme kategori som naturhistoriske samlinger. Det vil si at tilsetninger for å mykgjøre gjenstander, forhindre insektangrep og for å gi et estetisk utseende for gjenstandene på hver sin måte kan ha medført endringer i det originale materialet (kildematerialet) og i mange tilfeller virket nedbrytende. Alternative konserveringsmetoder bør tilpasses gjenstands- materialets sammensetning og egenskaper og man kan stille seg spørsmålet - i de tilfeller hvor gjenstanden tåler behandling eller må behandles - skal man vurdere bruk av tilsetningsstoffer/metoder som opprinnelig var benyttet i det regelmessige vedlikeholdet av gjenstandene innenfor de enkelte urfolks kultur?

Hvordan museer og institusjoner håndterer samlinger og gjenstander i forhold til de urfolk de representerer er et viktig arbeid i årene som kommer. Like viktig er det å ta vare på den til dels tause tradisjonelle kunnskapen som ligger innbygget i de ulike materialer og gjenstander som museene i dag forvalter.

Torunn Klokkernes, Det Kgl. Danske Kunstakademi, Konservatorskolen, København. NFR-Stipendiat (20042006) ved Kulturhistorisk Museum, Universitetet i Oslo.

Adresse: Kulturhistorisk Museum, Universitetet i Oslo, Postboks 6762, St. Olavs plass, 0130 Oslo, Norge. Tlf: + 4722859991 . Fax: + 4722859960

E-mail:torunn.klokkernes@khm.uio.no 